\title{
Finding a road to recovery
}

\author{
Rebecca Coombes head of news and views
}

The BMJ

This week The BMJ publishes a trio of education articles and an infographic that deal with the diagnosis and management of eating disorders in young people (doi:10.1136/bmj.j5245; doi:10. 1136/bmj.j5328; doi:10.1136/bmj.j5378; http://bit.ly/2jqgBO8).

As Helen Bould and colleagues report (doi:10.1136/bmj.j5245), the UK's annual incidence of eating disorders diagnosed in primary care among people aged 10-49 rose from 32.3 per 1000 in 2000 to 37.2 in 2009. Eating disorders are now fairly common among adolescent girls. A recent Dutch study found a lifetime prevalence among 19 year old women of 5.7\%, compared with $1.2 \%$ in men. Despite this prevalence, anorexia, bulimia, and binge eating disorder are often dangerously misunderstood. Population studies consistently find that many people meeting diagnostic criteria do not get any kind of treatment.

Bould and colleagues emphasise the importance of intervening early for better treatment outcomes. Outcomes in anorexia are especially poor if the patient does not receive effective treatment within the first three years. One characteristic of treating eating disorders is that the doctor must build a therapeutic relationship with the family, not just with the patient. What can be effective, they write, is "conceptualising eating problems as separate from the young person, so that parent and child can 'team up' against the disorder."
The tensions and benefits in this family dynamic are laid bare in Caitlin and her mother Sally's account of the 17 year old's struggle with anorexia (doi:10.1136/bmj.j5378). The BMJ's What Your Patient is Thinking articles are usually told in the first person, but this week's double header shows how perceptions differ between patients with an eating disorder and their carers.

Caitlin, who lost $10 \mathrm{~kg}$ in six months, thought she wasn't thin enough to be anorexic and took pride when people liked her skinny selfies on Instagram. Sally was able to offer insights Caitlin wasn't aware of, such as her total withdrawal from social groups offline. Good, structured care can make a difference: after a year in treatment, and with a detailed relapse prevention strategy, Caitlin is now in recovery.

Her advice to doctors? Explain that social media images are often altered or unrealistic: "I often wonder, if I had known about Photoshop, would I have become ill? If I knew these women were not real, would I have wanted to change so much?"

\section{Follow Rebecca on Twitter, @rebeccacoombes}

Published by the BMJ Publishing Group Limited. For permission to use (where not already granted under a licence) please go to http://group.bmj.com/group/rights-licensing/ permissions 